\title{
THE EFFECTS OF BREEDING STIMULI ON THE RATE OF SPERM TRANSPORT IN RABBITS
}

\author{
E. B. KREHBIEL, * J. R. LODGE AND O. P. SHARMA \\ Department of Dairy Science, University of Illinois, \\ Urbana 61801, U.S.A.
}

(Received 10th September 1971, accepted 13th December 1971)

Sperm transport through the female reproductive tract in mammals has been studied by several investigators. The results from these studies have shown that in the mouse (Lewis \& Wright, 1935), the rat (Blandau \& Money, 1944), the hamster (Yamanaka \& Soderwall, 1960), the cow (VanDemark \& Hays, 1951; Hays \& VanDemark, 1952), and the ewe (Mattner \& Braden, 1963), spermatozoa are present in the oviducts within minutes of mating or insemination. A rapid transport of spermatozoa to the rabbit oviduct has not previously been reported. The interval between mating and the finding of spermatozoa in the oviducts has ranged from $1 \mathrm{hr}$ (Chang, 1952) to 3 to $4 \mathrm{hr}$ (Braden, 1953) and, for sufficient spermatozoa to fertilize all of the eggs, to as much as 5 to $6 \mathrm{hr}$ (Adams, 1956; Greenwald, 1956). The early literature has been more completely reviewed by Fitzpatrick (1966).

This paper presents the results from a study comparing the effect of natural mating and artificial insemination on the rate of sperm transport in the rabbit.

Twenty-nine sexually mature New Zealand White female rabbits were used in the study. Sixteen females were naturally mated with fertile males and thirteen were artifically inseminated into the anterior vagina with semen collected from the same fertile males. Does were mated with from one to three different males or inseminated with the total ejaculate from a single male. The does were killed with an intravenous injection of Nembutal from 5 to $120 \mathrm{~min}$ after mating or artificial insemination. Clamps were immediately placed on the reproductive tract, dividing it into three regions-the anterior half of the vagina, the uterine horns and the oviduct. The vagina and uterine horn portions were each flushed with $3 \mathrm{ml}$ physiological saline into centrifuge tubes. The flushings were centrifuged for $10 \mathrm{~min}$ at $3000 \mathrm{rev} / \mathrm{min}$, and most of the supernatant was carefully removed by pipette.The sperm pellet was resuspended in the remaining supernatant and haemocytometer counts were made or aliquots were transferred to microscope slides and the presence of spermatozoa determined with the aid of a light microscope. Each portion of the oviduct was flushed with 0.25 $\mathrm{ml}$ saline directly onto microscope slides and the flushings were examined for sperm cells at a $\times 200$ magnification.

The results from naturally mated does (Table 1) show that 120 min after mating eight of ten oviducts contained spermatozoa and all of the uteri and vaginae contained spermatozoa. The two oviducts not containing spermatozoa

* Present address: Department of Zoology, Eastern Illinois University, Gharleston, Illinois 6120. 
were from the same doe. Spermatozoa were not found in the eight oviducts from does killed $60 \mathrm{~min}$ after mating but all uteri and vaginae contained spermatozoa. Spermatozoa were found in the oviducts as well as in the vagina and uterine horns of the doe killed 75 min after mating.

Spermatozoa were observed in all portions of the reproductive tract of animals killed 30 to $60 \mathrm{~min}$ after artificial insemination (Table 1). Six of the eight oviducts and uterine horns from animals killed $15 \mathrm{~min}$ after insemination contained spermatozoa. Spermatozoa were found in only one of four uterine horns and in none of four oviducts $5 \mathrm{~min}$ after insemination.

TABLE 1

THE RATE OF SPERM TRANSPORT IN RABBITS AT VARYING TIMES AFTER NATURAL MATING AND ARTIFICIAL INSEMINATION

\begin{tabular}{|c|c|c|c|c|c|c|c|}
\hline \multirow{2}{*}{$\begin{array}{l}\text { Breeding } \\
\text { stimulus }\end{array}$} & \multirow{2}{*}{$\begin{array}{l}\text { No. of } \\
\text { females }\end{array}$} & \multirow{2}{*}{$\begin{array}{c}\text { Time after } \\
\text { insemination } \\
\quad(\text { min })\end{array}$} & \multicolumn{5}{|c|}{ No. of tract portions containing sperm. } \\
\hline & & & $\begin{array}{r}C \\
\text { Left }\end{array}$ & uct & Left & $\begin{array}{l}\text { us } \\
\text { Right }\end{array}$ & Vagina \\
\hline $\begin{array}{l}\text { Natural } \\
\text { mating }\end{array}$ & $\begin{array}{l}5 \\
6 \\
6 \\
4\end{array}$ & $\begin{array}{r}120 \\
90 \\
75 \\
60\end{array}$ & $\begin{array}{l}4 \\
5 \\
5 \\
0\end{array}$ & $\begin{array}{l}4 \\
4 \\
4 \\
0\end{array}$ & $\begin{array}{l}5 \\
5 \\
5 \\
4\end{array}$ & $\begin{array}{l}5 \\
5 \\
5 \\
4\end{array}$ & $\begin{array}{l}5 \\
6 \\
6 \\
4\end{array}$ \\
\hline $\begin{array}{c}\text { Artificial } \\
\text { insem- } \\
\text { ination }\end{array}$ & $\begin{array}{l}3 \\
4 \\
4 \\
2\end{array}$ & $\begin{array}{r}60 \\
30 \\
15 \\
5\end{array}$ & $\begin{array}{l}3 \\
4 \\
3 \\
0\end{array}$ & $\begin{array}{l}3 \\
4 \\
3 \\
0\end{array}$ & $\begin{array}{l}3 \\
4 \\
3 \\
0\end{array}$ & $\begin{array}{l}3 \\
4 \\
3 \\
1\end{array}$ & $\begin{array}{l}3 \\
4 \\
4 \\
2\end{array}$ \\
\hline
\end{tabular}

These results show a different response in the rate of sperm transport following natural mating and artificial insemination in female rabbits. The slow transport following natural mating is in agreement with the reported literature and the rapid transport following insemination is similar to the findings for other species following either natural mating or insemination. It is believed, as reported by Hays \& VanDemark (1953) and VanDemark \& Hays (1951, 1954) for the cow, that oxytocin released during natural mating or insemination stimulates uterine muscle contractions resulting in rapid transport of spermatozoa through the female reproductive tract. The data reported here for the rabbit suggest that oxytocin is not released during natural mating but is released at the time of artificial insemination. The former part of this hypothesis is supported by the findings of Sharma \& Chaudhury (1970) who found that there was no release of oxytocin in the rabbit following successful mating.

This work was supported in part by the Illinois Agricultural Experiment Station.

\section{REFERENCES}

ADAMs, C. E. (1956) A study of fertilization in the rabbit: the effect of postcoital ligation of the Fallopian tube or uterine horn. F. Endocr. 13, 296.

Braden, A. W. H. (1953) Distribution of sperms in the genital tract of the female rabbit. Aust. F. biol. Sci. 6, 693.

BLANDAU, R. J. \& Money, W. L. (1944) Observations on the rate of transport of spermatozoa in the female genital tract of the rat. Anat. Rec. 90, 255. 
Chang, M. C. (1952) Fertilizability of rabbit ova and the effects of temperature in vitro on their subsequent fertilization and activation in vivo. 7. exp. Zool. 121, 351.

FitzPatrick, R. J. (1966) The posterior pituitary gland and the female reproductive tract. In: The Pituitary Gland, Vol. 3, Pars Intermedia and Neurohypophysis. Eds. G. W. Harris and B. T. Donovan. University of California Press, Los Angeles.

Greenwald, G. S. (1956) Sperm transport in the reproductive tract of female rabbit. Science, N.Y. 124, 586.

Hays, R. L. \& VANDemark, N. L. (1952) Effect of hormones on uterine motility and sperm transport in the perfused genital tract of the cow. F. Dairy Sci. 35, 499.

Hays, R. L. \& VanDemark, N. L. (1953) Effect of oxytocin and epinephrine on uterine motility in the bovine. Am. 7. Physiol. 172, 557.

LEWIS, W. H. \& WRIGHT, E. S. (1935) On the early development of the mouse egg. Carnegie Instn. Contrib. Embryol. 25, 115; cited by Yanagamachi, R. \& Chang, M. G. (1963) J. Reprod. Fert. 6, 413.

Mattner, P. E. \& Braden, A. W. H. (1963) Spermatozoa in the genital tract of the ewe. I. Rapidity of transport. Aust. 7. biol. Sci. 16, 473.

Sharma, S. C. \& Chaudhury, R. R. (1970) Studies on mating. Part 1. The absence of release of oxytocin at mating in female rabbits. Indian 7. med. Res. 58, 495.

VANDemark, N. L. \& Hays, R. L. (1951) The effect of oxytocin, adrenalin, breeding techniques, and milking on uterine motility in the cow. F. Anim. Sci. 10, 1083.

VanDemark, N. L. \& Hays, R. L. (1954) Rapid sperm transport in the cow. Fert. Steril. 5, 131.

Yamanaka, H. S. \& Soderwall, A. L. (1960) Transport of spermatozoa through the female genital tract of hamsters. Fert. Steril. 11, 470. 